\title{
Distribusi Ukuran dan Tingkat Kematangan Gonad Portunus pelagicus, Linnaeus, 1758 (Malacostraca : Portunidae) di Perairan Rembang, Jawa Tengah
}

\author{
Dina Ayu Magfirani*, Ervia Yudiati, Retno Hartati \\ Departemen IImu Kelautan, Fakultas Perikanan dan IImu Kelautan, Universitas Diponegoro \\ Jl. Prof H.Soedharto S H, Tembalang, Semarang, Jawa Tengah 50275 Indonesia \\ *Corresponding author, e-mail : dinakhatul@gmail.com
}

\begin{abstract}
ABSTRAK : Rajungan merupakan komoditas ekspor bernilai ekonomis penting dan memiliki nilai komersial yang tinggi. Tingginya permintaan pasar terhadap komoditas perikanan rajungan memicu eksploitasi yang berlebihan sehingga dapat berdampak terhadap kelestarian sumber daya rajungan. Penelitian ini bertujuan untuk mengetahui distribusi ukuran, hubungan lebar dan berat, distribusi TKG, serta nisbah kelamin rajungan (Portunus pelagicus) di Perairan Gegunung Wetan, Rembang. Penelitian ini terdiri dari pengukuran panjang dan lebar karapas, pengamatan tingkat kematangan gonad rajungan betina, serta pengamatan kualitas air (salinitas, suhu, pH, kedalaman dan kecerahan). Hasil dari penelitian ini menujukkan dari 3000 ekor rajungan yang diamati diketahui distribusi lebar karapas rajungan berkisar antara 7,3 - 16 $\mathrm{cm}$ dengan kisaran berat sebesar 47-262 gram. Rajungan yang tertangkap memiliki pertumbuhan yang bersifat allometrik negatif, dengan nilai $b$ sebesar 2,12 pada rajungan jantan, 1,65 pada rajungan betina. Faktor kondisinya adalah 1,1 pada jantan dan 1,02 pada betina. Sedangkan distribusi tingkat kematangan gonad rajungan betina adalah 762 ekor pada TKG 1; 700 ekor pada TKG 2; serta 388 ekor pada TKG 3.
\end{abstract}

Kata Kunci : Portunus pelagicus, Distribusi Ukuran, Tingkat Kematangan Gonad.

\section{Size Distribution and Gonad Maturity Stages of Blue Swimming Crab (Portunus pelagicus) at Gegunung Wetan Waters, Rembang, Central Java}

\begin{abstract}
Blue swimming crab has a high economical value. The production of blue swimming crab is exported overseas, so, therefore, triggers the excessive exploitation. This will lead to have an impact related to the sustainability of natural resource. This research aim to find out the size distribution, the relationship of carapace widht and body weight, gonad maturity stages distribution and sex ratio of blue swimming crab (P. pelagicus) at Gegunung Wetan Waters, Rembang. This consider to have a role as a tool on planning the farming and managing the blue swimming crab conservation. This research cover the length and width measurement of blue swimming crab carapace, gonad maturity stages observation of female blue swimming $\mathrm{crab}$ and water quality measurments (salinity, temperature, $\mathrm{pH}$, water depth and water brightness). The result showed that 3000 blue swimming crabs have $7.3-16 \mathrm{~cm}$ of widht carapace distribution and 47-262 gram of average weight. It can be concluded that growth are negatively allometric with $b$ value $(2,12)$ for the male crabs and $b$ value (1.65) for female crabs.. The condition factor of male crab is 1,1 and female crabs is 1,02. Based on the research, the result also shows that gonad maturition stages of female crabs were 762 crabs for stage 1, 700 crabs for stage 2 and 388 crabs for stage 3.
\end{abstract}

Keywords: Portunus pelagicus, Size distribution, Gonad maturity stages.

\section{PENDAHULUAN}

Rajungan ( $P$. pelagicus) merupakan biota laut yang banyak terdapat di perairan Indonesia. Rajungan di Indonesia sampai sekarang masih merupakan komoditas perikanan yang memiliki nilai ekonomis tinggi. Jumlah penangkapan Rajungan di alam semakin meningkat dan berdampak pada penurunan terhadap sumberdaya Rajungan setiap tahunnya. Sampai saat ini seluruh kebutuhan ekspor Rajungan masih mengandalkan dari hasil tangkapan di alam (Juwana et al., 2009). Nilai ekspor Rajungan yang tercatat pada tahun 2010 menempati urutan 
ketiga setelah udang dan tuna yaitu sejumlah 21.537 ton dengan nilai 208 juta dolar AS. Sedangkan untuk tahun 2014 mengalami peningkatan 28.091 ton dan mencapai nilai 414 juta dolar AS. Nilai ekspor produksi Rajungan di Indonesia mengalami peningkatan sebesar $27,81 \%$ pada periode tahun $2012-2017$.

Tingginya minat masyarakat terhadap kegiatan perikanan tangkap serta sifat pemanfaatan sumberdaya perikanan yang bersifat milik umum dan akses yang terbuka cenderung mendorong nelayan untuk memanfaatkan sumber daya secara berlebih (over exploited). Tingkat pemanfaatan Rajungan yang tinggi akan berdampak pada status stok Rajungan di perairan, terutama jika dilakukan terhadap Rajungan muda karena akan menghambat laju penambahan stok baru. Hal ini dikhawatirkan dapat berdampak pada populasi dan struktur ukuran Rajungan di alam (Hamid et al., 2015). Untuk itu perlu dilakukan kajian tentang ukuran dan kondisi reproduksi Rajungan yang tertangkap, apakah sudah sesuai dengan peraturan yang telah ditetapkan. Untuk menjaga kelestarian Rajungan di Perairan Gegunung Wetan, Rembang diperlukan pengelolaan berkelanjutan serta dibutuhkan informasi melalui penelitian tersebut dapat disusun suatu pengelolaan perikanan yang cukup tentang biologi reproduksi Rajungan.

Penelitian ini bertujuan untuk mengetahui distribusi ukuran, hubungan lebar karapas dan berat tubuh, distribusi tingkat kematangan gonad dan nisbah kelamin Rajungan ( $P$. pelagicus) yang tertangkap selama penelitian di Perairan Gegunung Wetan, Rembang.

\section{MATERI DAN METODE}

Penelitian dilakukan pada tanggal 21 Maret - 19 April 2019 di Perairan Gegunung Wetan, Rembang (Gambar 1). Materi penelitian meliputi sampel 3000 ekor Rajungan ( $P$. pelagicus) yang tertangkap selama penelitian dari salah satu pengepul di Perairan Gegunung Wetan, Rembang. Metode yang digunakan dalam penelitian ini adalah metode survey yang bersifat deskriptif. Pengambilan sampel rajungan dilakukan dengan metode purposive method sampling. Lebar karapas rajungan diukur dengan menggunakan jangka sorong atau kalier (dengan ketelitian 0,05). Berat tubuh rajungan ditimbang dengan menggunakan timbangan digital (dengan ketelitian 0,1 gram). Penentuan lokasi parameter lingkungan diamati secara in situ di lapangan dengan pertimbangan penentuan oleh nelayan berdasarkan perwakilan wilayah tangkapan.
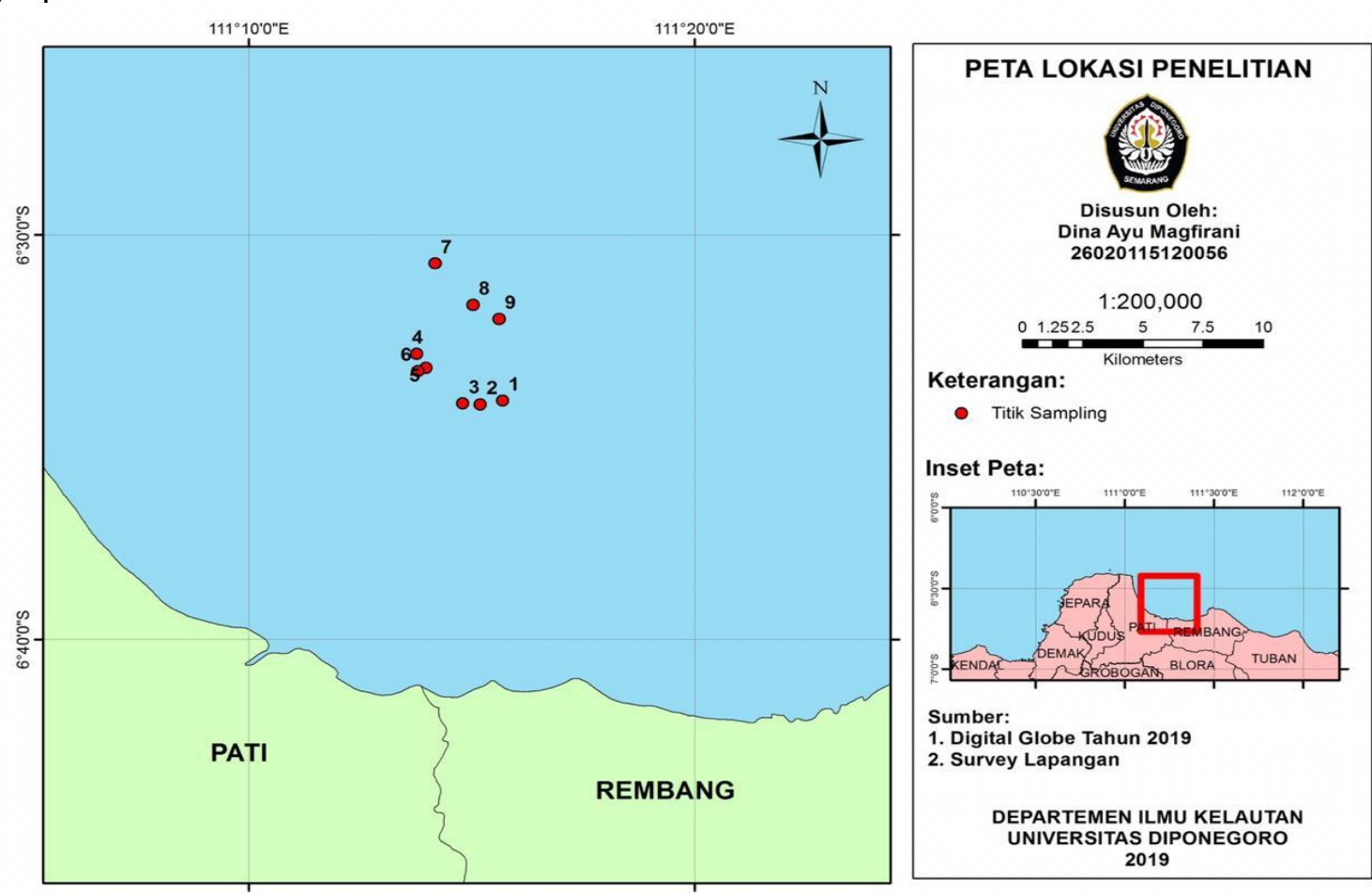

Gambar 1. Peta Lokasi Penelitian dan Pengukuran Parameter Lingkungan 


\section{Hubungan Lebar Karapas dan Berat} berikut :

Kangas (2000), menyatakan hubungan antara lebar dan berat tubuh diformasikan sebagai

$$
W=a L^{b}
$$

Keterangan : $\mathrm{W}=$ berat rajungan (gram); $\mathrm{a}=$ intersep (perpotongan kurva); $\mathrm{L}=$ lebar karapas $(\mathrm{mm}) ; \mathrm{b}=$ penduga pola pertumbuhan lebar karapas - berat

Uji yang dipakai adalah uji $t$ (t-test) yaitu dengan hipotesis : $\mathrm{H}_{0}: \mathrm{b}=3$ (isometrik); $\mathrm{H}_{1}: \mathrm{b} \neq 3$ (allometrik)

$$
\mathbf{T}_{\text {hitung }}=\frac{\mathrm{B}_{1}-\mathrm{B}_{0}}{\mathrm{Sb}}
$$

Keterangan : $B_{1}=$ nilai $b$ (koefisien $b$ ); $B_{0}=3 ; S_{b}=$ Simpangan baku

Pada selang kepercayaan $95 \%$ bandingkan nilai $\mathrm{T}_{\text {hitung }}$ dengan nilai $\mathrm{T}_{\text {tabel }}$ kemudian keputusan yang diambil untuk mengetahui pola pertumbuhan yaitu : $\mathrm{T}_{\text {hitung }}>\mathrm{T}_{\text {tabel }}$ : tolak hipotesis nol $\left(\mathrm{H}_{0}\right) ; \mathrm{T}_{\text {hitung }}<\mathrm{T}$ tabel : terima hipotesis nol $\left(\mathrm{H}_{0}\right)$

\section{Faktor Kondisi}

Perhitungan faktor kondisi terlebih dahulu diketahui pola pertumbuhan biota tersebut (Kangas, 2000). Jika pertumbuhan rajungan allometrik $(b \neq 3)$, maka persamaan yang digunakan adalah :

$$
\mathrm{Kn}=\mathrm{W} / \mathrm{aL}^{\mathrm{b}}
$$

Keterangan $: \mathrm{Kn}=$ Faktor kondisi rajungan; $\mathrm{W}=$ Berat $(\mathrm{gram}) ; \mathrm{L}=$ Lebar $(\mathrm{cm}) ; \mathrm{A}=$ Intersep (pertolongan kurva hubungan lebar berat dengan sumbu $y) ; b=$ Pendugaan pola pertumbuhan lebar dan berat

\section{Nisbah Kelamin}

Nisbah kelamin rajungan ditentukan berdasarkan rasio jumlah rajungan jantan terhadap rajungan betina yang diamati selama penelitian. Hamid (2015), persamaan dalam menentukan nisbah kelamin rajungan adalah :

$$
\mathrm{Nk}=\mathrm{Nj}: \mathrm{Nb}
$$

Keterangan $: \mathrm{Nk}=$ Nisbah kelamin; $\mathrm{Nj}=$ Jumlah rajungan jantan; $\mathrm{Nb}=$ Jumlah rajungan betina

Selanjutnya berdasarkan Tuhuteru (2018), untuk mengetahui keseimbangan nisbah kelamin menggunakan uji Chi-Square dengan persamaan sebagai berikut:

$$
\mathbf{X}^{2}=\Sigma \frac{(\mathrm{Oi}-\mathrm{ei})^{2}}{\text { ei }}
$$

Keterangan : $\mathrm{Oi}=$ frekuensi rajungan jantan dan betina yang teramati; ei $=$ frekuensi harapan,yaitu frekuensi rajungan jantan ditambah betina di bagi dua; $X^{2}=$ sebuah nilai bagi peubah acak $\mathrm{x}^{2}$ yang sebaran penarikan contohnya mendekat sebaran $\mathrm{x}^{2}$

Pada selang kepercayaan $95 \%$ dibandingkan antara $X^{2}$ hitung dengan $X_{\text {tabel }}$ kemudian keputusan yang diambil untuk mengetahui keseimbangan nisbah kelamin yaitu : Xhitung > Xtabel : Nisbah kelamin jantan dan betina tidak seimbang; Xhitung < Xtabel : Nisbah kelamin jantan dan betina seimbang

\section{Analisis Tingkat Kematangan Gonad (TKG)}

Analisis tingkat kematangan gonad berupa distribusi tingkat kematangan gonad rajungan betina menggunakan software Microsoft excel. Distribusi diicari dengan menghitung jumlah rajungan betina pada setiap tingkat kematangan gonad kemudikan disajikan kedalam grafik batang. 


\section{HASIL DAN PEMBAHASAN}

Distribusi Ukuran Rajungan disajikan dalam Tabel 1 dan histogramnya dapat dilihat pada Gambar 2. Distribusi ukuran berdasarkan dua kriteria $(<10 \mathrm{~cm}$ dan $>10 \mathrm{~cm})$ disajikan dalam Gambar 3. Dari data pada tabel dan gambar tersebut terlihat bahwa Rajungan dengan ukuran lebar karapas 10-10,9 cm mendominasi ukuran yang tertangkap.Distribusi frekuensi berat rajungan dan histogramnya dapat dilhat pada Tabel 2 dan Gambar 4 . Rajungan yang tertangkap sebagian besar didominansi dengan berat 101-108 gram.

Hasil analisis distribusi ukuran lebar karapas dengan rentang $0,9 \mathrm{~cm}$ didapatkan bahwa nilai tangkapan terendah adalah $7,3 \mathrm{~cm}$ dan tertinggi adalah $16 \mathrm{~cm}$. Distribusi ukuran lebar karapas tertinggi pada Rajungan jantan dan betina selama penelitian terdapat pada selang kelas $10-10,9 \mathrm{~cm}$ sebanyak 470 dan 804 ekor. Rajungan jantan yang tertangkap jantan pada stadia juvenile adal 7 ekor, 182 ekor stadia sub-adult (remaja) dan 961 ekor stadia dewasa,.

Tabel 1. Distribusi Frekuensi Lebar Karapas Rajungan ( $P$. pelagicus) Selama Penelitian di Perairan Gegunung Wetan, Rembang

\begin{tabular}{ccccc}
\hline No & Kelas $(\mathrm{cm})$ & Jumlah (ekor) & Jantan (ekor) & Betina (ekor) \\
\hline 1 & $7-7,9$ & 17 & 7 & 10 \\
2 & $8-8,9$ & 102 & 30 & 72 \\
3 & $9-9,9$ & 429 & 152 & 277 \\
4 & $10-10,9$ & 1274 & 470 & 804 \\
5 & $11-11,9$ & 820 & 329 & 491 \\
6 & $12-12,9$ & 279 & 122 & 157 \\
7 & $13-13,9$ & 65 & 35 & 30 \\
8 & $14-14,9$ & 12 & 4 & 8 \\
9 & $15-15,9$ & 1 & 1 & 0 \\
10 & $16-16,9$ & 1 & 0 & 1 \\
\hline \multicolumn{7}{c}{ Total } & 3000 & 1150 & 1850 \\
\hline
\end{tabular}

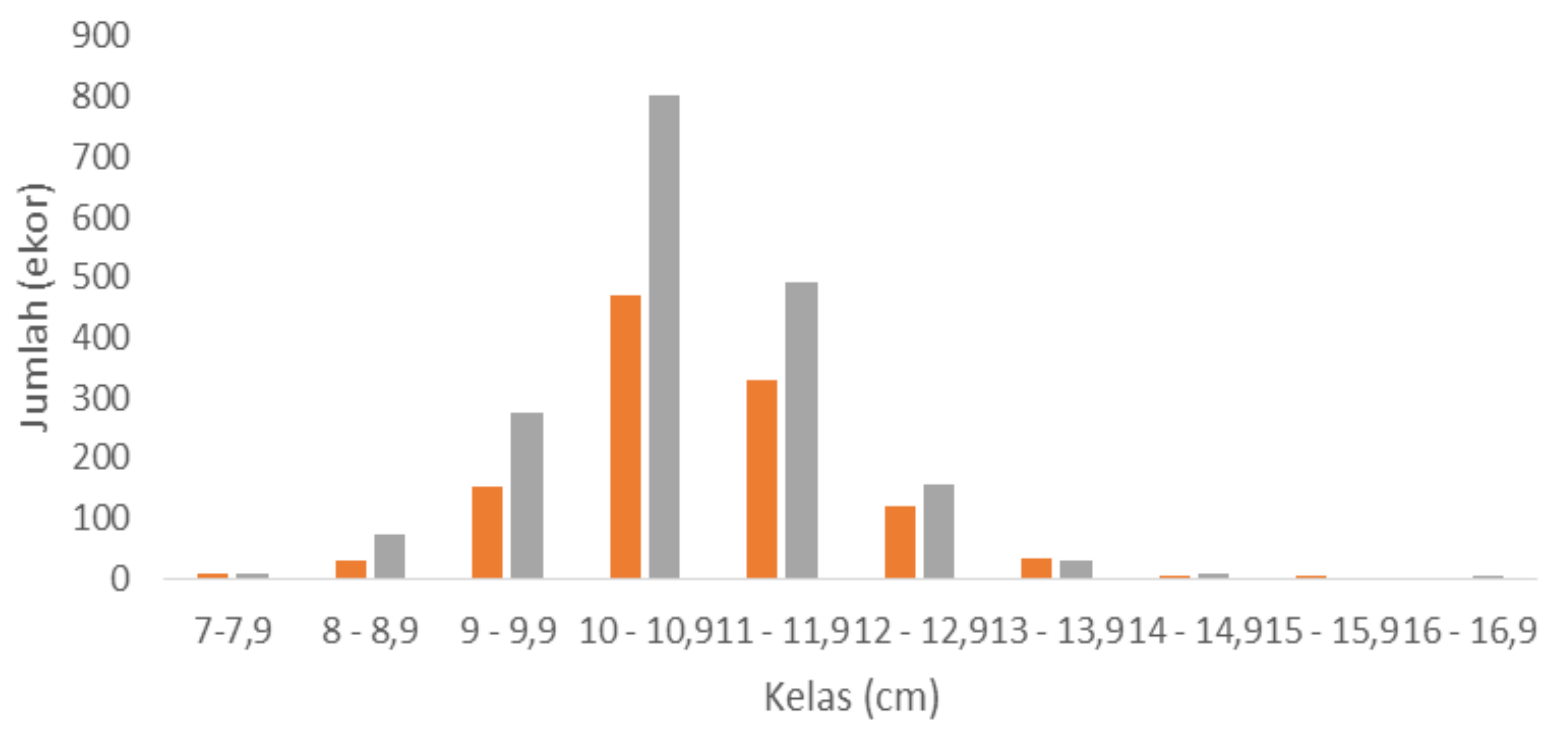

- Jumlah Jantan (ekor) घ Jumlah Betina (ekor)

Gambar 2. Distribusi Frekuensi Lebar Karapas Rajungan ( $P$. pelagicus) Selama Penelitian di Perairan Gegunung Wetan, Rembang 


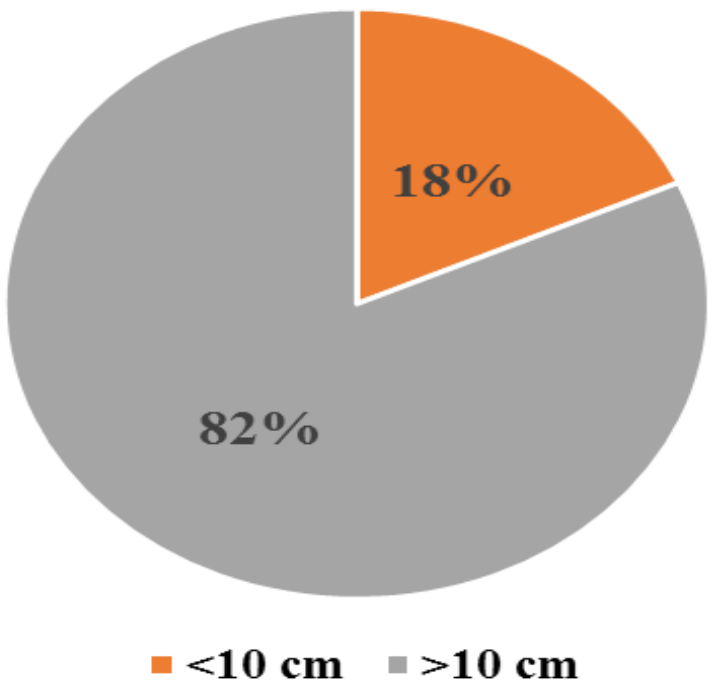

Gambar 3. Distribusi Frekuensi Lebar Karapas Rajungan ( $P$. pelagicus) Selama Penelitian di Perairan Gegunung Wetan, Rembang

Rajungan betina yang tertangkap adalah 10 ekor stadia juvenil, 349 ekor stadia sub-adult (remaja) dan 1491 ekor stadia dewasa. Banyaknya Rajungan jantan maupun betina stadia dewasa yang tertangkap pada kawasan Perairan Gegunung Wetan ini dikarenakan area penangkapan dilakukan diperairan laut dalam. Data pada penelitian ini sesuai dengan laporan dari Kangas (2000), mengatakan bahwa Rajungan dewasa akan bermigrasi ke laut dalam untuk melakukan pemijahan

Berdasarkan hasil analisis distribusi lebar karapas Rajungan jantan dan betina yang tertangkap selama penelitian, dapat dilihat bahwa ukuran lebar karapas Rajungan banyak yang berukuran $\geq 10 \mathrm{~cm}$, tetapi masih ada juga Rajungan yang tertangkap dengan ukuran $\leq 10 \mathrm{~cm}$. Terdapat $18 \%$ atau 548 ekor Rajungan tidak layak tangkap. Peraturan Menteri Kelautan dan Perikanan Republik Indonesia Nomor 1/PERMEN-KP/2015 Tentang Penangkapan Lobster (Panulirus spp.), Kepiting (Scylla spp.), dan Rajungan (Portunus spp.), menyampaikan mengenai larangan penangkapan Rajungan yang memiliki lebar karapas $\leq 10 \mathrm{~cm}$. Hal ini menunjukkan bahwa masih terdapat Rajungan jantan maupun betina yang tidak layak tangkap. Sesuai Kepmen tsb, seharusnya Rajungan berukuran kecil atau $\leq 10 \mathrm{~cm}$ wajib dilepaskan kembali oleh para nelayan. Hal ini bertujuan untuk menjaga kelestarian sumberdaya Rajungan di suatu perairan serta menjadi strategi dalam pengelolaan Rajungan yang berkelanjutan atau sustainablel, namun Rajungan dengan ukuran $\leq 10 \mathrm{~cm}$ masih tertangkap dan tidak dilepas. Hal ini dikarenakan nelayan dan pengepul yang belum sepenuhnya sadar dari diberlakukannya Peraturan Menteri Kelautan dan Perikanan Republik Indonesia Nomor 1/PERMEN-KP/2015. Nelayan. Salah satu yang menjadi pertimbangan adalah alasan ekonomi keluarga. Penangkapan Rajungan yang berukuran kecil atau $\leq 10 \mathrm{~cm}$ masih dapat berkembang dan bereproduksi sehingga dapat menambah kelestarian stok Rajungan diperairan dan terhindar dari tekanan populasi. Penangkapan Rajungan dengan ukuran $\leq 10 \mathrm{~cm}$ secara umum tidak mendukung pengelolaan perikanan yang berkelanjutan.

Hubungan Lebar Karapas dan Berat Tubuh Rajungan serta Faktor Kondisinya disajikan pada Tabel 3 dan Gambar 5. Pola pertumbuhan Rajungan jantan dan betina adalah sama yaitu allometrik negatif.

Hasil analisis hubungan lebar karapas dan berat Rajungan selama penelitian menunjukkan nilai $b$ yang didapat kurang dari tiga $(b<3)$ dan hasil uji $t$ square didapatkan keputusan $t_{\text {hitung }}>t_{\text {tabel }}\left(H_{0}\right.$ ditolak) maka pola pertumbuhan Rajungan bersifat allometrik negatif karena pada Rajungan jantan maupun betina memiliki nilai $b<3$ yaitu 2,12 pada jantan dan 1,65 pada betina. Hal ini menunjukkan bahwa pertumbuhan lebar karapas Rajungan lebih cepat 
Journal of Marine Research Vol.8, No.4 November 2019, pp. 367-378

Tabel 2. Distribusi Frekuensi Berat Rajungan ( $P$. pelagicus) Selama Penelitian di Perairan Gegunung Wetan, Rembang

\begin{tabular}{ccccc}
\hline No & Kelas (Gram) & Jumlah (Ekor) & Jantan (Ekor) & Betina (Ekor) \\
\hline 1 & $40-59$ & 16 & 9 & 7 \\
2 & $60-79$ & 269 & 89 & 180 \\
3 & $80-99$ & 857 & 261 & 596 \\
4 & $100-119$ & 916 & 319 & 597 \\
5 & $120-139$ & 547 & 235 & 312 \\
6 & $140-159$ & 205 & 115 & 90 \\
7 & $160-179$ & 105 & 70 & 35 \\
8 & $180-199$ & 56 & 33 & 23 \\
9 & $200-219$ & 22 & 14 & 8 \\
10 & $220-239$ & 3 & 2 & 1 \\
11 & $240-259$ & 3 & 3 & 0 \\
12 & $260-279$ & 1 & 0 & 1 \\
\hline \multicolumn{7}{c}{} & Total & 3000 & 1150 & 1850
\end{tabular}

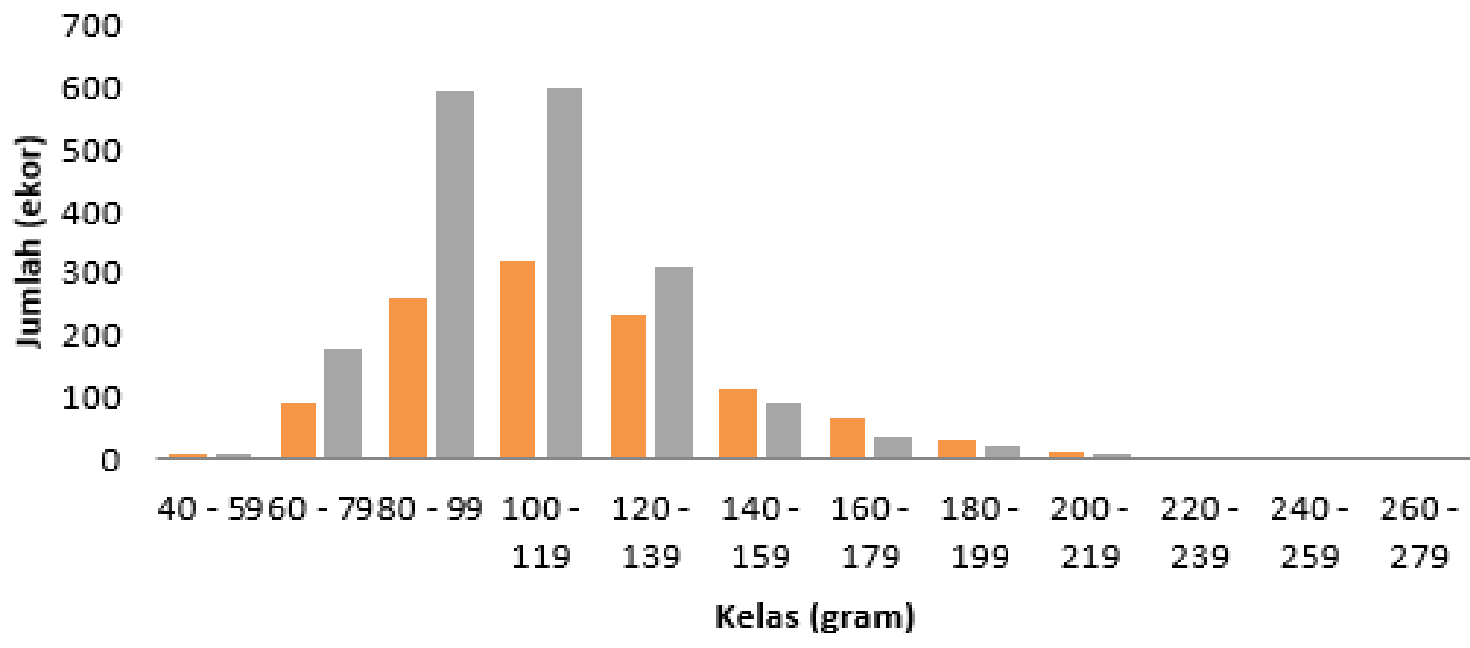

Jumlah Jantan (ekor) a Jumlah Betina (ekor)

Gambar 4. Distibusi Frekuensi Berat Rajungan ( $P$. pelagicus) Selama Penelitian di Perairan Gegunung Wetan, Rembang

Tabel 3. Hubungan Lebar Karapas dan Berat Rajungan ( $P$. pelagicus) dan Faktor Kondisi Selama Penelitian di Perairan Gegunung Wetan, Rembang

\begin{tabular}{ccccccc}
\hline Ratio Kelamin & $\mathrm{a}$ & $\mathrm{b}$ & $\mathrm{R}^{2}$ & $\mathrm{~W}=\mathrm{aL}^{\mathrm{b}}$ & Faktor Kondisi $^{\text {Petumbuhan }}$ & $\begin{array}{c}\text { Pola } \\
\text { Jantan }\end{array}$ \\
\hline Betina & 0,005 & 2,12 & 0,6 & $0,005 \mathrm{~L}^{2,12}$ & 1,1 & $\begin{array}{c}\text { Allometrik } \\
\text { Negatif }\end{array}$ \\
\hline & 0,047 & 1,65 & 0,5 & $0,047 \mathrm{~L}^{1,65}$ & 1,02 & $\begin{array}{c}\text { Allometrik } \\
\text { Negatif }\end{array}$
\end{tabular}

Keterangan : $a$ dan $\mathrm{b}=$ koefisien regresi; $\mathrm{R}^{2}=$ koefisien determinasi; $\mathrm{W}=$ berat Rajungan (gram); $\mathrm{L}=$ lebar karapas $(\mathrm{cm})$. 


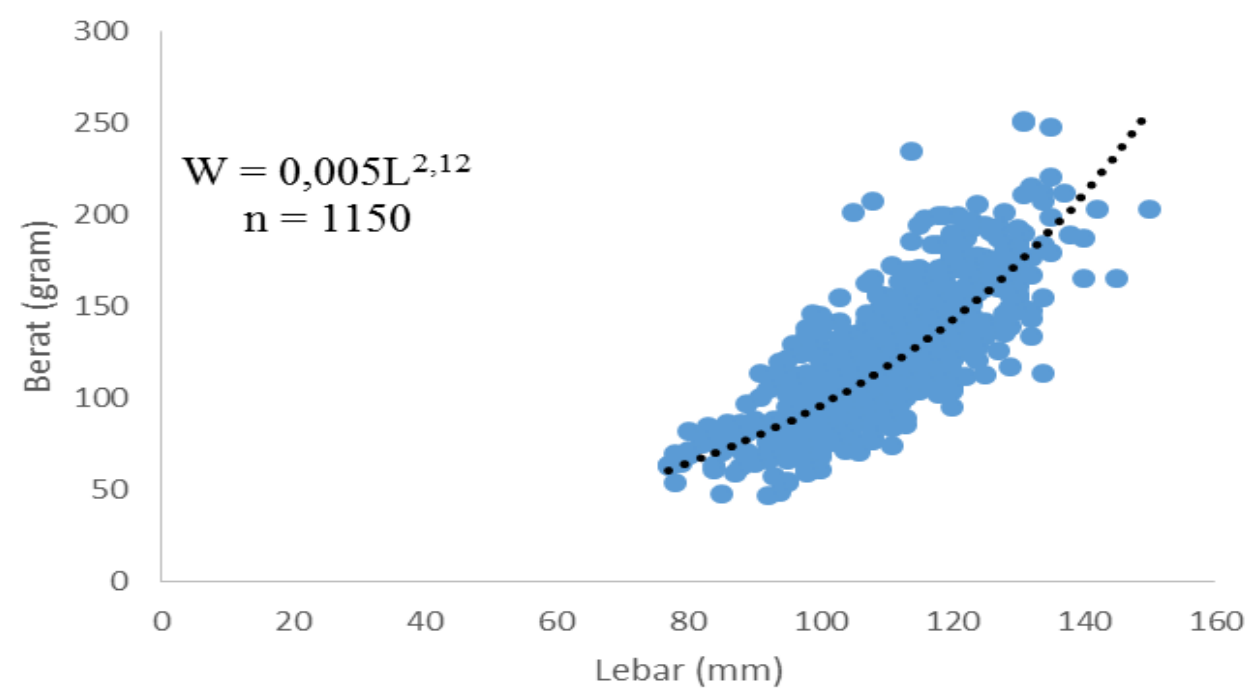

Gambar 5. Hubungan Lebar Karapas dan Berat Rajungan ( $P$. pelagicus) Jantan Selama Penelitian di Perairan Gegunung Wetan, Rembang

daripada pertumbuhan berat tubuhnya. Terdapat faktor luar yang dapat menyebabkan perbedaan pola pertumbuhan pada Rajungan jantan dan betina yaitu jumlah makanan di alam dan perbedaan iklim lokal yang tinggi seiring dengan perubahan musim. Selain itu, terdapat faktor internal sendiri yaitu anggota tubuh yang hilang, jenis kelamin dan tingkat kedewasaan (Hartnoll er al., 1982). Ketersediaan pakan alam di habitat yang mencukupi dapat menyebabkan pertumbuhan Rajungan relatif cepat, karena persediaan energi untuk digunakan dalam proses metabolisme tercukupi. Sedangkan terganggunya proses pertumbuhan Rajungan dapat disebabkan oleh tekanan penangkapan Rajungan yang tinggi (over exploited). Hamid (2015), menyatakan bahwa tingkat eksploitasi Rajungan yang melewati batas optimum atau telah terjadi tangkapan lebih (overfishing) berdampak pada penurunan keberhasilan perkawinan serta menimbulkan tekanan pada Rajungan betina yang belum matang gonad, sehingga berpotensi menurunkan keberlanjutan populasi Rajungan. Lingkungan perairan yang tidak sesuai dengan pertumbuhan Rajungan akibat menurunnya habitat yang ideal menyebabkan perubahan ketersediaan makanan. Abidin et al. (2014), menyatakan bahwa, pola penangkapan Rajungan yang tidak terkendali akan mengakibatkan terjadinya kerusakan lingkungan, dan kebutuhan makanan yang tidak terpenuhi sehingga menyebabkan laju tumbuh organisme tersebut akan terhambat. Offem et al. (2009), menyatakan bahwa ada beberapa faktor yang mempengaruhi perbedaan pertumbuhan panjang karapas dan berat yaitu suhu, salinitas, jenis kelamin, umur, waktu, dan area penangkapan.

Faktor internal yang mempengaruhi adalah genetik, tingkat kematangan gonad, dan jenis kelamin. Rajungan yang sudah matang gonad memiliki ukuran yang lebih besar dibandingkan yang belum matang gonad. Rajungan jantan memiliki karapas yang lebih panjang dibandingkan dengan Rajungan betina yang cenderung lebih berat, terutama pada saat Rajungan betina tersebut sedang membawa telur (De Lestang et al., 2003).

Faktor kondisi yang tersaji pada Tabel 3, pada Rajungan jantan adalah 1,1 dan 1,02 pada betina. Hal menunjukkan bahwa pertumbuhan bersifat allometrik negatif yang berarti pertambahan lebar lebih cepat dari berat. Salah satu Faktor yang penyebabnya adalah faktor lingkungan yaitu kurangnya ketersediaan makanan di perairan. Selain dipengaruhi oleh faktor eksternal, terdapat pula faktor internal, yaitu tingkat kematangan gonad, laju pertumbuhan, nafsu makan dan jumlah parasit pada tubuh Rajungan. Kemungkinan lain karena penangkapan Rajungan dilakukan pada bulan setelah berakhirnya masa pemijahan. Sesuai dengan Nurdin dan Teuku (2018) yang menyatakan nilai faktor kondisi Rajungan meningkat menjelang 
pemijahan dan akan menurun setelah melakukan pemijahan. Nisbah kelamin Rajungan disajikan pada Tabel 4 dan Gambar 7 yang menunjukkan kestidakseimbangan anatara Rajungan betina dan jantan.

Berdasarkan hasil penelitian diperoleh perbedaan ratio Rajungan jantan lebih kecil dibandingkan dengan Rajungan betina yaitu 1:1,6. Hasil penelitian ini berbeda dengan penelitian yang dilakukan Nugraheni (2015) yang menyatakan bahwa perbandingan Rajungan jantan dan betina di perairan Pati adalah 1:1,5. Perbedaan jumlah jantan dan betina dipengaruhi oleh beberapa faktor seperti musim, lokasi penangkapan, migrasi, ketersediaan makanan (La Sara et al., 2010). Pada musim pemijahan Rajungan yaitu pada bulan Maret, Juli, September, dan Desember, Rajungan betina akan bermigrasi ke perairan yang memiliki salinitas yang lebih tinggi. Sehingga pada musim - musim pemijahan daerah laut lepas didominasi oleh Rajungan betina (Romimoharto dan Juwana, 2005).

Berdasarkan Tabel 4 yaitu hasil perhitungan chi-square, didapatkan nilai Xhitung > Xtabel pada selang kepercayaan 95\%. Hal ini menunjukkan bahwa $\mathrm{H}_{0}$ ditolak, dengan maksud ratio jenis kelamin Rajungan antara jantan dan betina memiliki perbedaan yang nyata (tidak seimbang). Jumlah Rajungan betina lebih banyak daripada Rajungan jantan. Ketidakseimbangan antara Rajungan jantan dan betina terjadi karena pola hidup yang dipengaruhi oleh makanan yang tersedia, kepadatan populasi, dan keseimbangan makanan. Perbandingan yang berbeda pada sex ratio antara Rajungan jantan dan betina yang tertangkap oleh nelayan kemungkinan dikarenakan adanya perubahan perilaku dari masing - masing individu dalam mencari habitat yang sesuai, pengaruh dari penangkapan, mortalitas dan rekruitmen. Pada musim penghujan saat suhu perairan turun maka Rajungan akan berada pada kondisi tidak aktif, Rajungan akan banyak menghabiskan waktu mengubur diri dalam pasir untuk menjaga suhu tubuh agar tetap stabil (Kangas, 2000) dan kemungkinan Rajungan akan bermigrasi ke perairan yang lebih dalam (Dineshbabu et al., 2007). Hal ini kemungkinan juga bisa menjadi indikator terjadinya perbedaan sex ratio yang signifikan dari hasil tangkapan

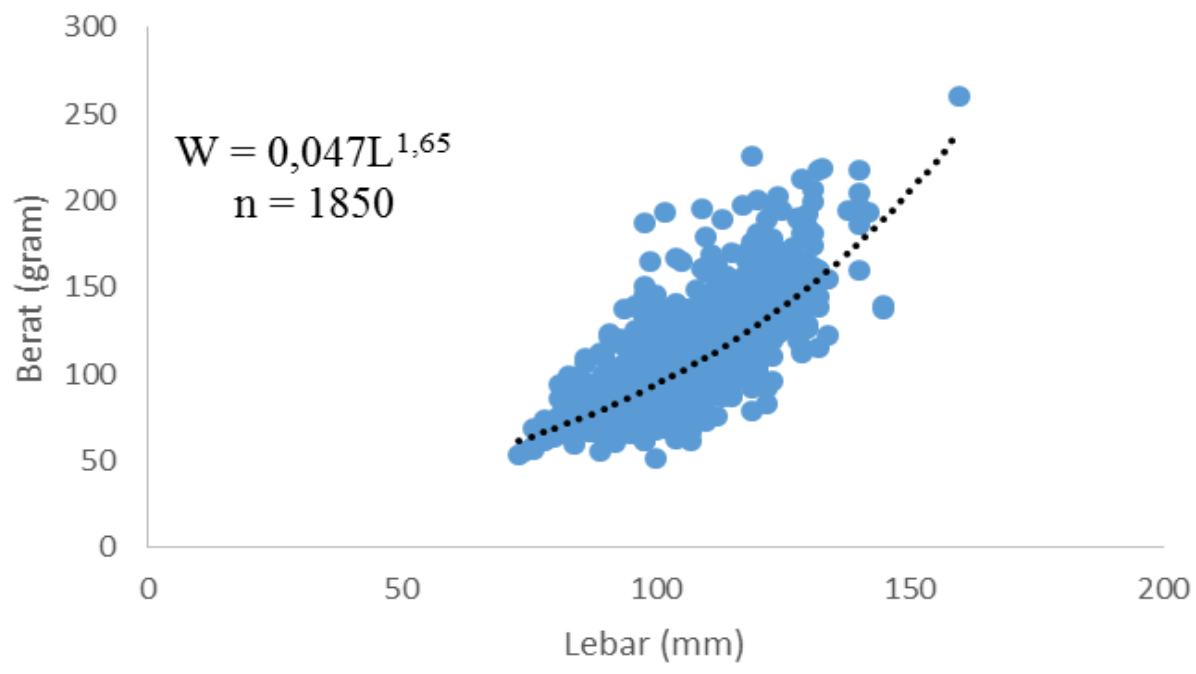

Gambar 6. Hubungan Lebar Karapas dan Berat Rajungan ( $P$. pelagicus) Betina Selama Penelitian di Perairan Gegunung Wetan, Rembang

Tabel 4. Nisbah Kelamin Rajungan ( $P$. pelagicus) Selama Penelitian di Perairan Gegunung Wetan, Rembang

\begin{tabular}{cccccccc}
\hline \multirow{2}{*}{$\begin{array}{c}\text { Lokasi } \\
\text { Penelitian }\end{array}$} & \multicolumn{2}{c}{ Jumlah } & \multicolumn{2}{c}{$\begin{array}{c}\text { Nisbah Kelamin } \\
\text { (Rasio) }\end{array}$} & \multirow{2}{*}{$\begin{array}{c}\mathrm{X}^{2} \\
\text { hitung }\end{array}$} & $\begin{array}{c}\mathrm{X} \\
\text { tabel }(\alpha 0,05)\end{array}$ & Keputusan \\
\cline { 2 - 5 } & Jantan & Betina & Jantan & Betina & & \\
\hline $\begin{array}{c}\text { Gegunung } \\
\text { Wetan }\end{array}$ & 1150 & 1850 & 1 & 1,6 & 163,34 & 74,97 & $\begin{array}{c}\text { Tidak } \\
\text { Seimbang }\end{array}$ \\
\hline
\end{tabular}


nelayan selama penelitian. Kamrani et al. (2010), juga menyatakan bahwa variasi sex ratio dapat disebabkan adanya migrasi yang dilakukan Rajungan betina untuk pemijahan pada beberapa periode dalam setahun yaitu pada bulan Maret, Juli, September dan Desember. Penelitian ini dilakukan pada bulan Maret, kemungkinan bahwa bulan Maret merupakan musim pemijahan yang artinya Rajungan betina akan bermigrasi dari tempat awal ke tempat yang bersalinitas tinggi untuk melakukan pemijahan. Migrasi Rajungan betina diduga mempengaruhi hasil tangkapan nelayan yang didominasi Rajungan betina karena pergerakan Rajungan betina tersebar di perairan luas.

Perbandingan Rajungan jantan dan betina yang tidak seimbang perlu mendapatkan perhatian. Tingginya Rajungan betina yang tertangkap berakibat buruk pada kelestarian Rajungan, karena dapat mengurangi/ menghambat proses penambahan stok di daerah tersebut. Hal ini sesuai Tirtadanu et al. (2017), yang menyatakan bahwa proses penambahan populasi bisa terhambat disebabkan menurunnya populasi Rajungan betina, hal ini disebabkan oleh kondisi periaran yang berkaitan dengan suhu, salinitas dan musim pemijahan dimana Rajungan betina lebih menyukai kondisi perairan dengan suhu yang rendah dengan salinitas yang tinggi sedangkan Rajungan jantan lebih menyukai suhu yang tinggi serta salinitas yang rendah (Kangas, 2000).

Distribusi tingkat kematangan gonad disajikan pada Tabel 6. Tingkat Kematangan Gonad Rajungan betina yang tertangkap pada TKG 1 adalah $41,2 \%$ atau berjumlah 762 ekor, TKG 2 adalah $37,8 \%$ atau berjumlah 700 ekor, TKG 3 adalah $21 \%$ atau berjumlah 388 ekor. Presentase Rajungan betina yang berukuran $\leq 10 \mathrm{~cm}$ yaitu $19,4 \%$ atau berjumlah 359 ekor.

Data ini menunjukkan masih terdapat hasil tangkapan Rajungan yang tidak sesuai dengan aturan yang sudah ditetapkan. Data sebaran tingkat kematangan gonad juga dapat menunjukkan terdapat Rajungan yang berukuran $\leq 10 \mathrm{~cm}$ yang sudah mencapai tingkat kematangan gonad 3, dari data tersebut menjelasan bahwa pada kondisi tertentu Rajungan yang berukuran kecil dapat mencapai matang gonad lebih cepat. Hal ini kemungkinan dapat disebabkan oleh faktor banyaknya penangkapan Rajungan betina tingkat kematangan gonad 3 atau Rajungan dewasa yang dilakukan para nelayan di Perairan Gegunung Wetan, Rembang, sehingga terjadinya penekanan populasi pada Rajungan betina.

Rajungan betina yang tertangkap di Perairan Gegunung Wetan, Rembang didominasi oleh Rajungan betina yang belum matang gonad dengan jumlah 1462 ekor (79\%). Hal ini berbeda dengan perairan Kepulauan Aru, dan perairan tenggara Australia, yang di dominasi oleh yang Rajungan betina yang sudah matang gonad (Kembaren, 2018). Terdapat beberapa faktor yang mempengaruhi dominasi TKG Rajungan pada suatu perairan. Nugraheni (2015), menyebutkan bahwa puncak pemijahan di perairan daerah Pati ada pada bulan Oktober, sedangkan bulan Januari-Maret dan Juni - Agustus pada perairan Brebes dan puncak musim

pemijahan di perairan timur Lampung adalah pada bulan April-Juni dan SeptemberOktober/November (Zairion, 2015). Hal ini dapat menjelaskan bahwa perbedaan tingkat kematangan gonad pada masing-masing lokasi penelitian, salah satunya disebabkan oleh perbedaan musim pemijahan. Selain itu temperatur perairan juga mempengaruhi tingkat kematangan gonad Rajungan, karena pada suhu hangat perkembangan ovarium lebih cepat (Svane dan Hooper, 2004).

Rajungan betina yang sudah matang gonad tingkat 3 atau membawa telur berjumlah 388 ekor atau $21 \%$ dari total Rajungan betina yang tertangkap. Peraturan Menteri Kelautan dan Perikanan Republik Indonesia Nomor 1/PERMEN-KP/2015 Tentang Penangkapan Lobster (Panulirus spp.), Kepiting (Scylla spp.), dan Rajungan (Portunus spp.), menyampaikan mengenai larangan penangkapan Rajungan betina yang sedang membawa telur (ovigerous). Hasil penelitian ini menujukkan bahwa para nelayan di Perairan Gegunung Wetan, Rembang masih belum mematuhi peraturan pemerintah dan bila penangkapan Rajungan betina yang matang gonad 3 atau membawa telur terus ditangkap oleh para nelayan maka hal tersebut dapat menyebabkan penurunan populasi dan menghambat penambahan stok Rajungan di perairan tersebut sehingga para nelayan kemungkinan akan melaut lebih jauh lagi dari tahun sebelumnya untuk mendapatkan hasil tangkapan Rajungan. Kualitas perairan merupakan salah satu faktor yang membantu kelangsungan hidup Rajungan di suatu populasi. Pengukuran data 
parameter lingkungan diambil secara in-situ di 9 titik dilokasi penangkapan Rajungan. Hasil parameter lingkungan disajikan pada Tabel 6.

Tabel 5.Distribusi Tingkat Kematangan Gonad Berdasarkan Ukuran Lebar Karapas Rajungan Selama Penelitian di Perairan Gegunung Wetan, Rembang

\begin{tabular}{ccccc}
\hline \multirow{2}{*}{ No } & Kelas $(\mathrm{cm})$ & \multicolumn{3}{c}{ Tingkat Kematangan Gonad } \\
\cline { 3 - 5 } & & TKG I & TKG II & TKG III \\
\hline 1 & $7-7,9$ & 10 & 0 & 0 \\
2 & $8-8,9$ & 69 & 3 & 0 \\
3 & $9-9,9$ & 156 & 73 & 48 \\
4 & $10-10,9$ & 295 & 330 & 179 \\
5 & $11-11,9$ & 158 & 230 & 103 \\
6 & $12-12,9$ & 63 & 58 & 36 \\
7 & $13-13,9$ & 8 & 5 & 17 \\
8 & $14-14,9$ & 3 & 1 & 4 \\
9 & $15-15,9$ & 0 & 0 & 0 \\
10 & $16-16,9$ & 0 & 0 & 1 \\
\hline & Total & 762 & 700 & 388 \\
\hline
\end{tabular}

Tabel 6. Parameter Lingkungan Selama Penelitian di Perairan Gegunung Wetan, Rembang

\begin{tabular}{cccc}
\hline No & Parameter & Hasil Pengukuran & Kondisi Optimal \\
\hline 1 & Suhu $\left({ }^{\circ} \mathrm{C}\right)$ & $28-30$ & $28-32$ (Juwana, 1997) \\
2 & Salinitas $(\% \circ)$ & $31-33$ & $20-36$ (Juwana, 1997) \\
3 & $\mathrm{pH}$ & $7-8$ & $6,5-8,5$ (Juwana, 1997) \\
4 & Kedalaman $(\mathrm{m})$ & $5-15$ & $10-25$ (Kembaren, 2018) \\
5 & Kecerahan $(\mathrm{m})$ & $2,75-3$ & $2,8-3,4$ (Nugraheni, 2015) \\
\hline
\end{tabular}

Parameter lingkungan menunjukkan nilai suhu berkisar $28-30^{\circ} \mathrm{C}$. Salinitas yang didapatkan paling rendah 31\% dan tertinggi 33\%o. Pada pengukuran pH didapatkan hasil 7 - 8 . Kecerahan paling tinggi $2,75 \mathrm{~m}$ dan paling rendah $3 \mathrm{~m}$. Sedangkan kedalaman perairan yang diukur selama penelitian yaitu berkisaran $5-15 \mathrm{~m}$. Berdasarkan data hasil pengukuran parameter lingkungan diperoleh hasil yang normal, sehingga perairan Gegunung Wetan, Rembang masih dikatakan optimal untuk siklus hidup dan tingkah laku Rajungan di perairan tersebut sehingga dapat berkembang biak dengan baik. .

\section{KESIMPULAN}

Distribusi ukuran lebar karapas Rajungan di Perairan Gegunung Wetan rembang menunjukkan hasil yaitu berkisaran antara 7,3 - 16 cm dan kisaran berat tubuh sebesar $47-$ 262 gram, dengan pola pertumbuhan menunjukan bersifat Allometrik Negatif. Distribusi tingkat kematangan gonda Rajungan menunjukan hasil yaitu TKI I ; 762 ekor, TKG II ; 700 ekor, TKG III ; 388 ekor dan nisbah kelamin menunjukkan hasil perbandingan ratio jantan : betina yaitu 1 : 1,6 .

\section{UCAPAN TERIMA KASIH}

Artikel ini merupakan bagian dari skripsi yang berjudul "Analisis Distribusi Ukuran dan Tingkat Kematangan Gonad Rajungan (Portunus pelagicus) di Perairan Gegunung Wetan, 
Rembang". untuk memperoleh gelar Sarjana Strata Satu Program Studi IImu Kelautan, Fakultas Perikanan dan Ilmu Kelautan Universitas Diponegoro.

\section{DAFTAR PUSTAKA}

Abidin, Z., Bambang, A.N, \& Wijayanto, D. 2014. Manajemen Kolaboratif untuk Introduksi Pengelolaan Rajungan yang Berkelanjutan di Desa Betahwalang, Demak. Journal of Fisheries Resources Utilization Management and Technology, 4(3):29-36.

De Lestang, S., Hall, N.G. \& Potter, I.C. 2003. Reproductive biology of the blue swimmer crab (Portunus pelagicus, Decapoda: Portunidae) in five bodies of water on the west coast of Australia. Fishery Bulletin. 101(4):745-757.

Dineshbabu, A.P., Sreedhara, B. \& Muniyappa, Y. 2007. Fishery and Stock Assessment of Portunus sanguinolentus (Herbst) from South Karnataka Coast, India. Journal of the Marine Biological Association of India, 49(2):134-140.

Hamid, A. \& Wardiatno, Y. 2015. Population dynamics of the blue swimming crab (Portunus pelagicus Linnaeus, 1758) in Lasongko Bay, Central Buton, Indonesia. AACL Bioflux, 8 (5):729-739.

Hartnoll, R.G. 1982. Mating in the Brachyura. Crustaceana. 16(2):161-181

Juwana, S. 1997. Tinjauan tentang Perkembangan Penelitian Budidaya Rajungan (Portunus pelagicus, Linn). Oseana. 22 (4): 1-12.

Juwana, S., A. Aziz, \& Ruyitno. 2009. Evaluasi Potensi Ekonomis Pemacuan Stok Rajungan di Perairan Teluk Klabat, Pulau Bangka. Oseanologi dan Limnologi di Indonesia, 35 (2):107128

Kamrani, E., Sabili, A.N. \& Yahyavi, M. 2010. Stock assessment and reproductive biology of the blue swimming crab, Portunus pelagicus in Bandar Abbas Coastal Waters, Northern Persian Gulf. Journal of the Persian Gulf (Marine Science), 1(2):11-21.

Kangas, M.I. 2000. Synopsis of the biology and exploitation of the blue swimmer crab Portunus pelagicus Linnaeus in WesternAustralia. Fisheries Research Report No. 121. 2-22

Kembaren, Duranta D., \& Surahman, A. 2018. Struktur Ukuran dan Biologi Populasi Rajungan (Portunus pelagicus Linnaeus, 1758) di Perairan Kepulauan Aru. Jurnal Penelitian Perikanan Indonesia, 24(1):2-5

La Sara. 2010. Study on The Size Structure and Population Parameters of Mud Crab Scyllaserrata in Lawele Bay, Southeast Sulawesi, Indonesia. Journal of Coastal Development, 13(2):133-147.

Nugraheni, D.I. 2015. Variasi Ukuran Lebar Karapas dan Kelimpahan Rajungan (Portunus pelagicus) di Perairan Kabupaten Pati. Jurnal IImu dan Teknologi Kelautan Tropis, 7(2): 493-510.

Nurdin. M.H, \& Teuku, F.H. 2018. Faktor Kondisi Rajungan (Portunus pelagicus) yang Tertangkap pada Ekosistem Mangrove, Lamun, dan Terumbu Karang di Pulau Salemo Sulawesi Selatan. Jurnal IImiah Samudra Akuatika. 2(1):9-13

Offem, B.O., Akegbejo-Samsons, Y. \& Omoniyi, I.T. 2009. Biologicalassessment of Oreochromis niloticus (Pisces: Cichlidae: Linne:1958) in a tropical floodplain river. African Journal of Biotechnology, 6(16):1966-1971.

Romimohtarto, K \& Juwana, S. 2015. Biologi Laut IImu Pengetahuan tentang Biota Laut. Djambatan. Jakarta.

Svane, I., \& Hooper, G.E. 2004. Blue Swimmer Crab (Portunus pelagicus) Fishery. Fishery Assessment Report to PIRSA for Blue Crab Fishery Management Committee South Australian Research and Development Institute. Aquatic Sciences Publication. 3:274.

Tirtadanu \& Suman, A. 2017. Aspek Biologi, Dinamika Populasi Dan Tingkat Pemanfaatan Rajungan (Portunus Pelagicus Linnaeus, 1758) di Perairan Kotabaru, Kalimantan Selatan. Jurnal Penelitian Perikanan Indonesia. 23(3):205-214 
Tuhuteru, T. \& U. Chodrijah. 2018. Parameter Populasi dan Tingkat Pemanfaatan Kepiting Bakau (Scylla serratal Forsskal, 1775) di Perairan Sebatik, Kalimantan Utara. Jurnal Penelitian Perikanan Indonesia. 24(3):187-196 